\title{
Polysiphonia japonica extract suppresses the Wnt/ß-catenin pathway in colon cancer cells by activation of $\mathrm{NF}-\mathrm{KB}$
}

\author{
JUNGSUG GWAK $^{1 *}$, SEOYOUNG PARK ${ }^{1 *}$, MUNJU CHO $^{1}$, TAEYUN SONG ${ }^{1}$, SEON-HEUI CHA ${ }^{2}$, \\ DONG-EUN KIM ${ }^{3}$, YOU-JIN JEON ${ }^{2}$, JAE-GOOK SHIN ${ }^{4}$ and SANGTAEK OH ${ }^{1}$ \\ ${ }^{1}$ PharmcoGenomic Research Center, Inje University, Busan 614-735; ${ }^{2}$ Faculty of Applied Marine Science, \\ Cheju National University, Jeju 690-756; ${ }^{3}$ Department of Biotechnology \& Bioengineering, Dong-Eui University, \\ Busan 614-714; ${ }^{4}$ Department of Pharmacology, Inje University College of Medicine, Busan 633-165, Korea
}

Received December 30, 2005; Accepted February 17, 2006

\begin{abstract}
Abnormal activation of the $\mathrm{Wnt} / \mathrm{ß}$-catenin pathway and subsequent up-regulation of $\beta$-catenin response transcription (CRT) are associated with the development of colon cancer. Thus, the $\mathrm{Wnt} / \mathrm{B}$-catenin pathway is an attractive target for chemoprevention and treatment of this cancer. We used a cell-based screen to identify a methanol extract of Polysiphonia japonica (EPJ) that suppresses the Wnt/ß-catenin pathway without altering the level of $\beta$-catenin protein and reduces the expression of cyclin D1, which is a known Bcatenin/T cell factor (TCF)-dependent gene. EPJ inhibited the growth of various colon cancer cells. In addition, EPJ induced the nuclear translocation of nuclear factor- $\kappa \mathrm{B}(\mathrm{NF}-\kappa \mathrm{B})$ in SW480 colon cancer cells. Our findings suggest that EPJ attenuates $\mathrm{Wnt} / \mathrm{\beta}$-catenin signaling via activation of $\mathrm{NF}-\kappa \mathrm{B}$ and can potentially be used as a chemopreventive agent against colon cancer.
\end{abstract}

\section{Introduction}

The Wnt signaling pathway plays important roles in developmental processes and tumorigenesis (1-3). A key control of this pathway is the regulation of $\beta$-catenin activity, which depends on its intracellular protein level. In the presence of the Wnt signal, the signal is transduced the protein disheveled to negatively regulate glycogen synthase kinase-3ß (GSK-3ß), resulting in the accumulation of intracellular B-catenin (4-6).

Correspondence to: Dr Sangtaek Oh, PharmcoGenomic Research Center, Inje University, Busan 633-165, Korea

E-mail: ohsa@inje.ac.kr

Dr Jae-Gook Shin, Department of Pharmacology, Inje University College of Medicine, Busan 633-165, Korea

E-mail: phshinjg@inje.ac.kr

${ }^{*}$ Contributed equally

Key words: colon cancer, nuclear factor-кB, Polysiphonia japonica, Wnt/ß-catenin pathway
In the absence of the Wnt signal, $\beta$-catenin is associated with a multiprotein complex that is composed of adenomatous polyposis coli (APC), Axin, and GSK-3ß (7-11) and leads to the degradation of $\beta$-catenin through a ubiquitin-dependent mechanism $(12,13)$.

Inactive mutations of the APC tumor suppressor gene occur in the majority of sporadic colorectal cancers as well as in familial adenomatous polyposis (FAP) $(9,10)$. In addition, mutations in the $\beta$-catenin gene sequences encoding the phosphorylation motifs in its $\mathrm{N}$-terminal domain have been observed in colorectal cancer and melanoma (11). These mutations result in an excessive accumulation of $\beta$-catenin in the nucleus and stimulation of its target genes, including cyclin D1, myc, matrix metalloproteinase-7, and PPAR- $\delta$, which play important roles in tumorigenesis (14-17). Thus, the constitutive activation of $\mathrm{Wnt} / \mathrm{B}$-catenin signaling is a potential target for the chemoprevention and treatment of colorectal cancer.

We identified EPJ, which inhibits Wnt/ß-catenin signaling, through a cell-based screen in the present study. EPJ may suppress $\beta$-catenin response transcription (CRT) through crossregulation of the $\mathrm{Wnt} / \mathrm{B}$-catenin and $\mathrm{NF}-\kappa \mathrm{B}$ pathways in colon cancer cells.

\section{Materials and methods}

Cell culture, plasmid, transfection, and luciferase assay. HEK293, HCT116, SW480, HCT15, DLD-1, and Wnt3asecreting L cells were obtained from the American Type Culture Collection and maintained in Dulbecco's modified Eagle medium (DMEM) supplemented with $10 \%$ fetal bovine serum (FBS), $120 \mu \mathrm{g} / \mathrm{ml}$ penicillin, and $200 \mu \mathrm{g} / \mathrm{ml}$ streptomycin. For Wnt3a conditioned medium (Wnt3a CM), Wnt3asecreting L cells were cultured in DMEM with $10 \%$ FBS for 4 days. The medium was harvested and sterilized using a 0.22 -mm filter. Fresh medium was added, and the cells were cultured for another 3 days. The medium was collected and combined with the previous medium. Human Frizzled cDNA was cloned from SW480 cDNA (Clontech) by PCR and then subcloned into pCDNA3.1 (Invitrogen). The pTOPflash reporter plasmid was obtained from Upstate Biotechnology (Lake Placid, NY, USA). Transfection was carried out with 
Lipofectamine 2000 (Invitrogen) according to the manufacturer's instructions. Luciferase assays were performed using the dual luciferase assay kit (Promega).

Preparation of extract. Species of marine algae (126) used in the study were gathered from the seashore around Jeju from February to April 2004 and identified botanically at the Faculty of Applied Marine Science in Cheju National University. The algae were cleaned, lyophilized and then ground into fine powder. The powdered sample $(1 \mathrm{~g})$ was extracted for $24 \mathrm{~h}$ with $80 \%$ methanol under continuous shaking at room temperature. The methanol extracts were then concentrated in vacuum at $40^{\circ} \mathrm{C}$ in a rotary evaporator and stored at $4^{\circ} \mathrm{C}$.

Cell-based screening. The HEK293 reporter cell line was established by selecting HEK293 cells co-transfected with the plasmid expressing hFz-1 and TOPFlash, using media containing G418 $(1 \mathrm{mg} / \mathrm{ml})$. The cells were inoculated into 96-well plates at 15,000 cells per well in duplicate and grown for $24 \mathrm{~h}$. Wnt3a CM was added, and the extracts were then added to the wells. After $15 \mathrm{~h}$, the plates were assayed for firefly luciferase activity and cell viability.

Western blotting. The cytosolic and nuclear fraction was prepared as previously described (18). Proteins were separated by $4-12 \%$ gradient SDS-PAGE (Invitrogen) and transferred to a nitrocellulose membrane (Amersham Biosciences). The membranes were blocked with $5 \%$ nonfat milk and probed with anti-ß-catenin (BD Transduction Laboratories), antip65 (Santa Cruz Biotechnology), anti-cyclin D1 (Santa Cruz Biotechnology), and anti-actin antibodies (Cell Signaling Technology). After washing, the membranes were incubated with horseradish peroxidase-conjugated anti-mouse IgG or anti-rabbit IgG (Santa Cruz Biotechnology), and the bands were visualized using the ECL system (Santa Cruz Biotechnology).

Immunofluorescence analysis. SW480 cells were cultured on glass chamber slides and treated with either methanol or EPJ for $15 \mathrm{~h}$. After treatment, the cells were washed with PBS, fixed with $4 \%$ formaldehyde, permeabilized in $0.3 \%$ Triton $\mathrm{X}-100$, and blocked in $4 \%$ bovine serum albumin for $1 \mathrm{~h}$. The cells were stained with anti-p65 antibody and then analyzed by confocal microscopy using a Zeiss LSM510 Meta microscope.

Cell viability assay. Cells were inoculated into 96-well plates and treated with EPJ for $48 \mathrm{~h}$. The cell viability from each treated sample was measured in triplicate using Cell titerGlo assay kit (Promega) according to the manufacturer's instructions.

\section{Results}

Identification of EPJ as an inhibitor of the Wnt/ $\beta$-catenin pathway. We established reporter cell lines, which were stably transfected with a TOPFlash reporter and the human Frizzeled-1 (hFz-1) expression plasmid, to screen for extracts that could inhibit Wnt/B-catenin signaling. When the HEK293 reporter cells were incubated with Wnt3a-conditioned medium (Wnt3a CM), TOPFlash reporter activity dramatically
(A)

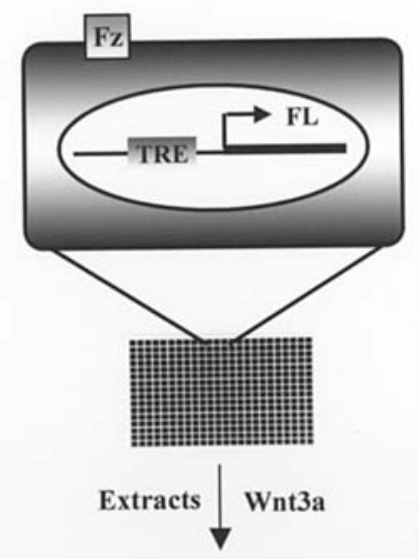

$\beta$-catenin response transcription

(B)

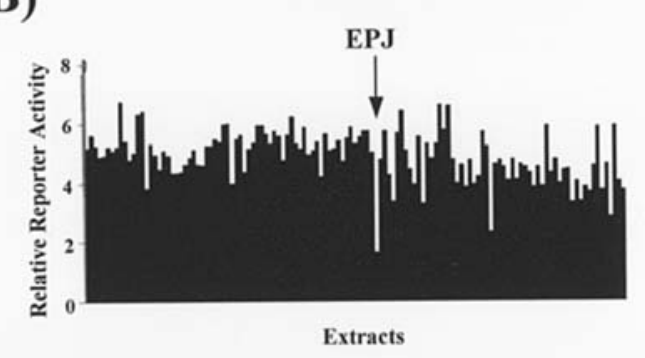

(C)

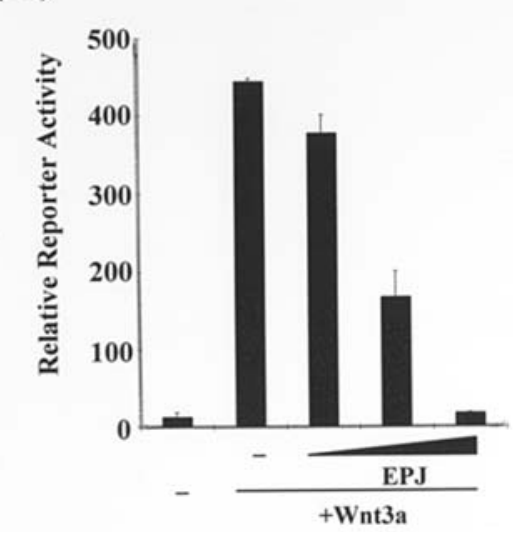

Figure 1. Identification of Polysiphonia japonica extract as an inhibitor of Wnt/B-catenin signaling. (A) A schematic of the screening system. (B) Screening of extracts that inhibit Wnt/B-catenin signaling. Extracts modulating TOPFlash reporter activity were screened using the HEK293 reporter cells. The controls were assayed in the presence or absence of Wnt3a CM. TOPFlash activities were normalized with Cell titer-Glo (Promega) activity. (C) HEK293 reporter cells were incubated with increasing concentrations of EPJ $(10,20$ and $40 \mu \mathrm{g} / \mathrm{ml})$ in the presence of Wnt3a CM. After $15 \mathrm{~h}$, luciferase activity was determined. The results are the average of three experiments, and the bars indicate standard deviations.

increased (data not shown). Using this system, we screened 126 methanol extracts from marine algae (Fig. 1A). One of the extracts identified from this screen was an extract of Polysiphonia japonica (EPJ) (Fig. 1B). As shown in Fig. 1C, 
(A)

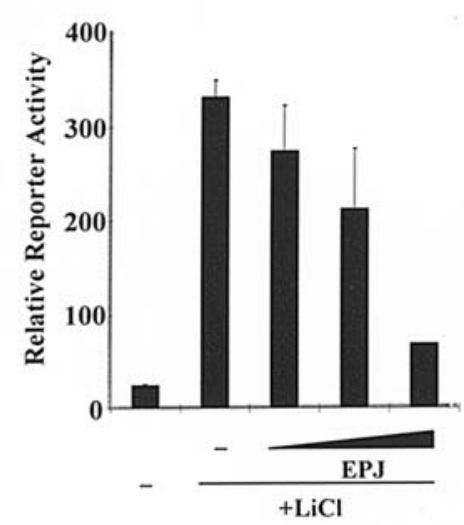

(B)

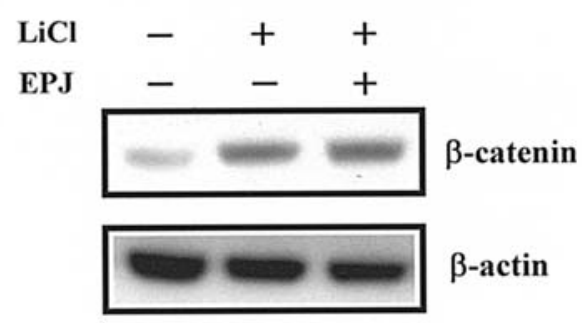

Figure 2. EPJ inhibits Wnt/ß-catenin signaling without altering $\beta$-catenin levels. (A) HEK293 reporter cells were incubated with increasing concentrations of EPJ $(10,20$ and $40 \mu \mathrm{g} / \mathrm{ml})$ in the presence of $20 \mathrm{mM} \mathrm{LiCl}$. After $15 \mathrm{~h}$, luciferase activity was determined. The results are the average of three experiments, and the bars indicate standard deviations. (B) Cytosolic proteins were prepared from HEK293 reporter cells treated with either vehicle (methanol) or EPJ (20 and $40 \mu \mathrm{g} / \mathrm{ml}$ ) in the presence of $20 \mathrm{mM} \mathrm{LiCl}$ for $15 \mathrm{~h}$ and then subjected to Western blotting with $\beta$-catenin antibody. The blots were reprobed with anti-actin antibody as a loading control.

treatment with EPJ resulted in a concentration-dependent decrease in the CRT that had been induced by Wnt3a CM.

EPJ does not affect the level of $\beta$-catenin. HEK293 reporter cells were incubated with $\mathrm{EPJ}$ and $\mathrm{LiCl}$, which specifically inhibits GSK-3ß, to investigate the molecular mechanism of the EPJ-induced $\mathrm{Wnt} / \mathrm{ß}$-catenin signaling inhibition. This procedure led to an accumulation of intracellular $\beta$-catenin and the activation of CRT (19). As shown in Fig. 2A, EPJ was able to inhibit LiCl-induced CRT. Therefore, EPJ inhibits Wnt/ßcatenin signaling by acting on $\beta$-catenin itself or its downstream components. In Wnt/ß-catenin signaling, CRT is dependent on the intracellular $\beta$-catenin level, which is regulated by ubiquitin-dependent degradation. To examine the possibility that EPJ affects the intracellular $\beta$-catenin level, we performed Western blotting with anti- $\beta$-catenin antibody to determine the amount of cytosolic $\beta$-catenin in response to EPJ. As shown in Fig. 2B, the level of $\beta$-catenin that accumulated in the presence of $\mathrm{LiCl}$ was not changed by EPJ treatment.

EPJ represses CRT in colon cancer cells. We tested the effect of EPJ on colon cancer cells because mutations that lead to the accumulation of $ß$-catenin are frequently observed in colon
(A)

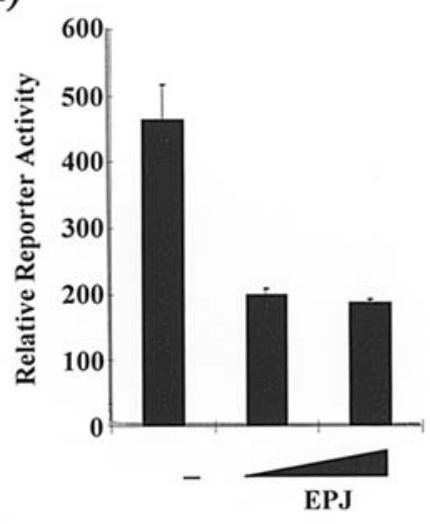

(B)

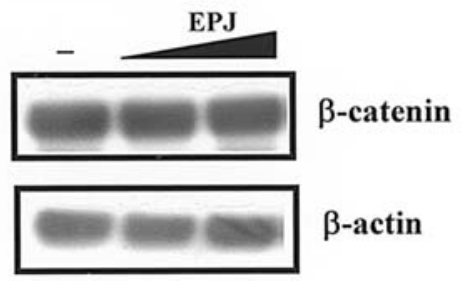

Figure 3. EPJ inhibit CRT in SW480 colon cancer cells. (A) SW480 cells were co-transfected with TOPFlash and pCMV-RL plasmids and incubated with increasing amounts of EPJ (20 and $40 \mu \mathrm{g} / \mathrm{ml})$ for $15 \mathrm{~h}$. Luciferase activities were measured $39 \mathrm{~h}$ after transfection. Results are the average of three experiments, and the bars indicate standard deviations. (B) Cytosolic proteins were prepared from SW480 cells treated with the vehicle (methanol) or EPJ (20 and $40 \mu \mathrm{g} / \mathrm{ml}$ ) for $15 \mathrm{~h}$ and then subjected to Western blotting with ß-catenin antibody. To confirm equal loading, the blot was re-probed with anti-actin antibody.

cancer (11). SW480 colon cancer cells, which contain mutanttype APC $(20,21)$, were transfected with TOPFlash and then treated with EPJ. Consistent with the result in the reporter cells, incubation with EPJ resulted in a decrease of CRT in the SW480 cells (Fig. 3A). In addition, Western blot analysis using $\beta$-catenin antibody showed that EPJ did not affect the intracellular B-catenin level in the SW480 cells (Fig. 3B). These results suggest that EPJ inhibits $\mathrm{Wnt} / \mathrm{B}$-catenin signaling without altering the intracellular $\beta$-catenin level.

EPJ down-regulates cyclin D1 and inhibits the proliferation of colon cancer cells. The cyclin D1 gene has been shown to be a $\beta$-catenin-dependent gene and to play a critical role in colon carcinogenesis $(22,23)$. Thus, we investigated whether EPJ affects the expression of cyclin D1 in SW480 cells. SW480 cells were treated with EPJ for $15 \mathrm{~h}$; we then determined the cyclin D1 protein level in response to EPJ treatment. Western blot analysis showed that the expression of cyclin D1 protein was down-regulated following the incubation with EPJ (Fig. 4A). Previous studies have demonstrated that disruption of the $B$-catenin function reduces the growth of human colon cancer cells $(20,21)$. Because EPJ inhibits $\beta$ catenin activity, we postulated that EPJ would also inhibit the growth of colon cancer cells. To address this issue, we 

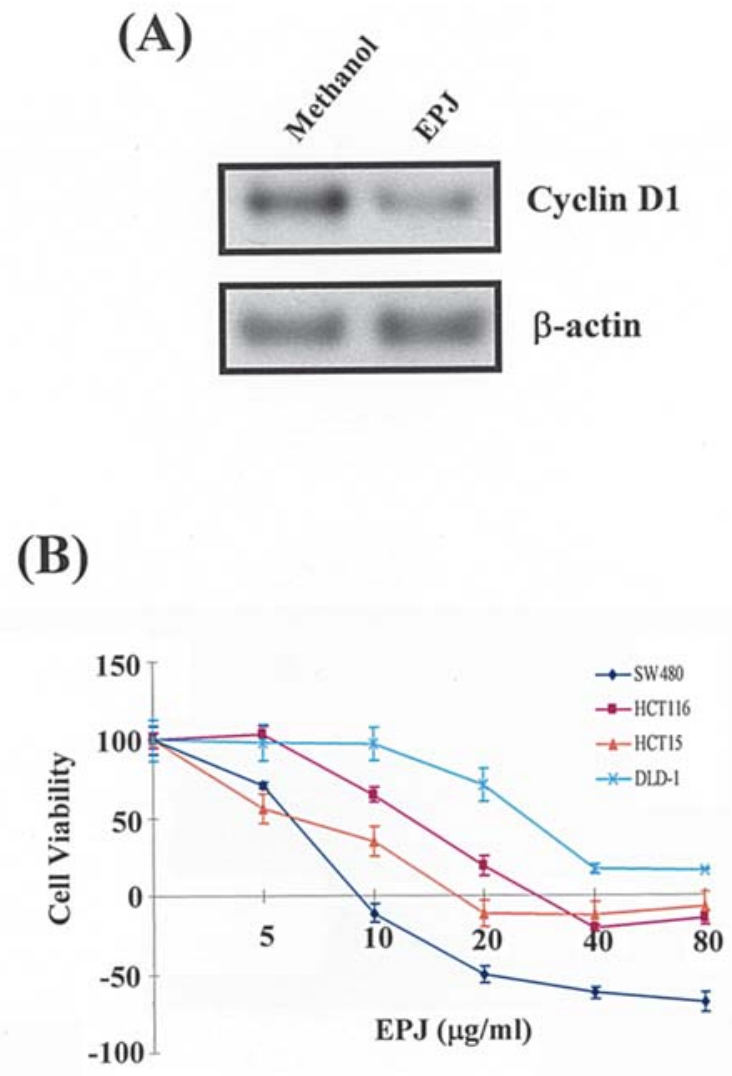

Figure 4. The effect of EPJ on colon cancer cells. (A) EPJ inhibits the expression of the TCF/B-catenin target gene. SW480 cells were incubated with the vehicle (methanol) or EPJ ( $40 \mu \mathrm{g} / \mathrm{ml})$ for $15 \mathrm{~h}$. Nuclear extracts were prepared for Western blotting with anti-cyclin D1 antibody. To confirm equal loading, the blot was re-probed with anti-actin antibody. (B) Cytotoxic effect of EPJ on colon cancer cells. Cells were incubated with the indicated concentrations of EPJ for $48 \mathrm{~h}$ in 96-well plates, and cell viability was determined as described in Materials and methods. To calculate the inhibition of growth, the value at time 0 was first subtracted. The results shown are the average of three experiments, and the bars indicate standard deviations.

examined the effect of EPJ on the growth of human colon cancer cells, including SW480, HCT-15, HCT116, and DLD-1. The cells were incubated with various concentrations of EPJ, and cell viability was measured. As shown in Fig. 4B, EPJ efficiently inhibited the growth of the tested colon cancer cells. The $\mathrm{IC}_{50}$ values for the SW480, HCT-15, HCT116, and DLD-1 cells were $6.7,6.5,14.5$, and $30.8 \mu \mathrm{g} / \mathrm{ml}$, respectively; indicating that EPJ is efficacious at inhibiting the proliferation of various colon cancer cells.

EPJ activates the $N F-\kappa B$ pathway. In our previous study, we demonstrated that $\mathrm{Wnt} / \mathrm{B}$-catenin signaling is attenuated by activation of the NF- $\kappa \mathrm{B}$ pathway without an alteration in the intracellular ß-catenin level in colon cancer cells (24). Our data show that EPJ also suppresses Wnt/B-catenin signaling without changing the $\beta$-catenin level. Thus, we asked whether EPJ induces NF- $\mathrm{KB}$ signaling in SW480 colon cancer cells. Upon the activation of NF- $\kappa B$ signaling, the NF- $\mathrm{BB}$ that dissociates from $\mathrm{I} \kappa \mathrm{B}$, which is the NF- $\mathrm{BB}$ inhibitor protein, is translocated into the nucleus; this process is followed by the induction of a wide variety of genes involved in inflammation, cell proliferation, and apoptosis (25-27). Therefore, we first examined
(A)

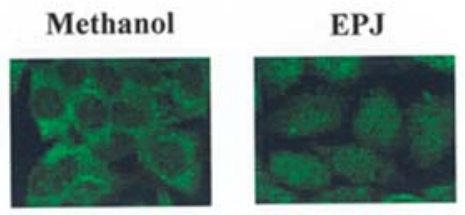

(B)

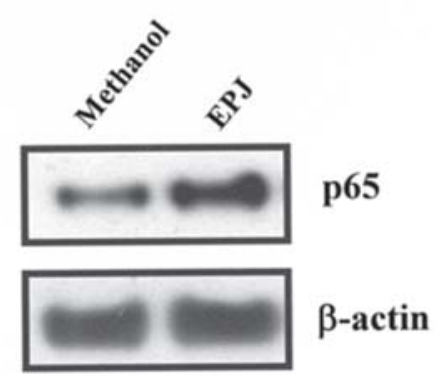

(C)

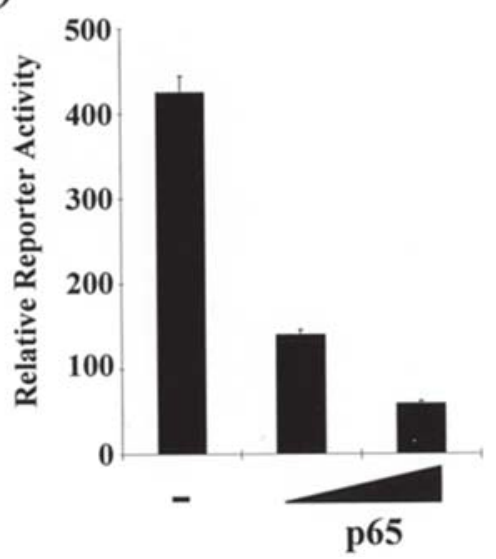

Figure 5. EPJ induces the degradation of $\mathrm{I} \kappa \mathrm{B} \alpha$ and the nuclear translocation

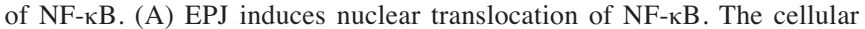
location of NF- $\kappa \mathrm{B}$ in SW480 cells treated with methanol and EPJ $(40 \mu \mathrm{g} / \mathrm{ml})$ was determined by immunofluorescence analysis. After fixation, the cells were stained with anti-p65 antibody and observed at x400 magnification. (B) Nuclear proteins from SW480 cells treated with EPJ $(40 \mu \mathrm{g} / \mathrm{ml})$ were subjected to Western blotting with anti-p65 antibody. The blots were reprobed with anti-actin antibody as a loading control. (C) SW480 cells were co-transfected with TOPflash and pCMV-p65. At $48 \mathrm{~h}$ after transfection, the luciferase activity was measured. The results are shown as the average of three experiments; the bars indicate standard deviations.

the location of NF-кB in the EPJ-treated SW480 colon cancer cells. Immunofluorescence analysis using anti-p65 antibody showed that $\mathrm{p} 65$, a subunit of NF- $\mathrm{KB}$, was primarily detected in the cytoplasm in vehicle (methanol)-treated cells (Fig. 5A). However, when SW480 cells were incubated with EPJ, the nuclear accumulation of p65 was observed (Fig. 5A). We also confirmed the EPJ-induced nuclear translocation of NF- $\mathrm{NB}$ using Western blot analysis. In agreement with the immunofluorescence analysis, the level of p65 in the nuclear fraction 
was increased in response to treatment with EPJ (Fig. 5B). Moreover, the ectopic expression of p65 repressed CRT in SW480 cells (Fig. 5C). Taken together, these results indicate that treatment with EPJ inhibits the $\mathrm{Wnt} / \mathrm{B}$-catenin pathway by stimulation of $\mathrm{NF}-\kappa \mathrm{B}$ signaling in SW480 colon cancer cells.

\section{Discussion}

Previous studies have indicated that mutations in a component of the $\mathrm{Wnt} / \mathrm{B}$-catenin pathway, leading to the up-regulation of B-catenin response transcription (CRT), are linked to the development of several cancers, including colon cancer and melanoma $(10,28)$. In this study, we identified an extract from $P$. japonica (EPJ) that inhibits $\mathrm{Wnt} / ß$-catenin signaling through cell-based screening. We also demonstrated that EPJ decreased CRT through a GSK-3ß-independent mechanism and without degradation of $\beta$-catenin. EPJ also suppressed the expression of cyclin D1, which is one of the B-catenin/TCF-dependent genes. In addition, EPJ had a growth inhibitory effect on various colorectal cancer cells. Most cancer cells that are resistant to chemotherapeutic agents contain mutant p53. EPJ showed effective cytotoxicity in cell lines containing wildtype p53 (HCT116) and mutant-type p53 (SW480). More importantly, EPJ efficiently inhibited the growth of multidrugresistant (MDR) positive cells, which present serious problems for anticancer therapeutics.

$\mathrm{NF}-\kappa \mathrm{B}$ is composed of two subunits, p65 and p50, and is normally retained in the cytoplasm by an inhibitory protein,

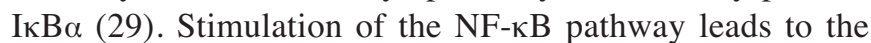
phosphorylation and subsequent degradation of $\mathrm{I} \kappa \mathrm{B} \alpha$, which then allows NF-кB to translocate to the nucleus (30). Crossregulation between the $\mathrm{Wnt} / \mathrm{B}$-catenin and $\mathrm{NF}-\kappa \mathrm{B}$ pathways has been demonstrated (31). In addition, ectopic expression of p65 (Rel A), which is a component of NF-kB, was found to repress the CRT that had been induced by the overexpression of mutant $\beta$-catenin (32). Recently, a nonsteroidal antiinflammatory drug (NSAID), diclofenac, was shown to inhibit Wnt/B-catenin signaling through the activation of the NF- $\mathrm{B}$ pathway and without altering the level of the $B$-catenin protein (24). Therefore, the NF- $\mathrm{KB}$ pathway may be a target mechanism for EPJ-mediated CRT inhibition. In the present study, EPJ induced the accumulation of p65 in the nucleus, suggesting that EPJ may suppress the Wnt/ß-catenin signaling via the activation of NF- $\mathrm{KB}$ in colon cancer cells. Taken together, EPJ can be developed into a new chemopreventive agent against colorectal cancer.

\section{Acknowledgements}

This study was supported by a grant (p-2004-02) from Marine Bioprocess Research Center of the Marine Bio 21 Center funded by the Ministry of Maritime Affairs \& Fisheries and a grant of Korea Health 21 R\&D Project, Ministry of Health \& Welfare, Republic of Korea (A050307).

\section{References}

1. Miller JR: The Wnts. Genome Biol 3: 3001.1-3001.15, 2001.

2. Korinek V, Barker N, Morin PJ, Van Wichen D, De Weger R, Kinzler KW, Vogelstein B and Clevers H: Constitutive transcriptional activation by a B-catenin-Tcf complex in APC-/-colon carcinoma. Science 275: 1784-1787, 1997.
3. Morin PJ, Sparks AB, Korinek V, Barker N, Clevers H, Vogelstein B and Kinzler KW: Activation of B-catenin-Tcf signaling in colon cancer by mutations in B-catenin or APC. Science 275: 1787-1790, 1997

4. Lee E, Salic A, Kruger R, Heinrich R and Kirschner MW: The roles of APC and Axin derived from experimental and theoretical analysis of the Wnt pathway. PLoS Biol 1: 116-132, 2003.

5. Dominguez I and Green JB: Dorsal downregulation of GSK3ß by a non-Wnt-like mechanism is an early molecular consequence of cortical rotation in early Xenopus embryos. Development 127: 861-868, 2000

6. Polakis P: Casein kinase 1: a Wnt'er of disconnect. Cur Biol 12: R499-R501, 2002.

7. Giles RH, Van Es JH and Clevers H: Caught up in a Wnt storm: Wnt signaling in cancer. Biochim Biophys Acta 1653: 1-24, 2003.

8. Matsuzawa SI and Reed JC: Siah-1, SIP, and Ebi collaborate in a novel pathway for B-catenin degradation linked to p53 responses. Mol Cell 7: 915-926, 2001.

9. Liu J, Stevens J, Rote CA, Yost HJ, Hu Y, Neufeld KL, White RL and Matsunami N: Siah-1 mediates a novel B-catenin degradation pathway linking p53 to the adenomatous polyposis coli protein. Mol Cell 7: 927-936, 2001.

10. Fearnhead NS, Britton MP and Bodmer WF: The ABC of APC. Hum Mol Genet 10: 721-733, 2001.

11. Morin PJ: ß-catenin signaling and cancer. Bioessays 21: 1021-1030, 1999.

12. Orford K, Crockett C, Jensen JP, Weissman AM and Byers SW: Serine phosphorylation-regulated ubiquitination and degradation of B-catenin. J Biol Chem 272: 24735-24738, 1997.

13. Aberle H, Bauer A, Stappert J, Kispert A and Kemler R: B-catenin is a target for the ubiquitin-proteasome pathway. EMBO J 16: 3797-3804, 1997.

14. Tetsu $\mathrm{O}$ and McCormick F: $\beta$-catenin regulates expression of cyclin D1 in colon carcinoma cells. Nature 398: 422-426, 1999.

15. He TC, Sparks AB, Rago C, Hermeking H, Da Costa LT, Zawel L, Morin PJ, Vogelstein B and Kinzler KW: Identification of c-MYC as a target of the APC pathway. Science 281: 1509-1512, 1998

16. Takahashi M, Tsunoda T, Seiki M, Nakamura Y and Furukawa Y: Identification of membrane-type matrix metalloproteinase-1 as a target of the $\mathrm{B}$-catenin/Tcf4 complex in human colorectal cancers. Oncogene 21: 5861-5867, 2002.

17. He TC, Chan TA, Vogelstein B and Kinzler KW: PPAR $\delta$ is an APC-regulated target of nonsteroidal anti-inflammatory drugs. Cell 99: 335-345, 1999.

18. Topol L, Jiang X, Choi H, Garrett-Beal L, Carolan PJ and Yang Y: Wnt-5a inhibits the canonical Wnt pathway by promoting GSK3-independent $B$-catenin degradation. J Cell Biol 162: 899-908, 2003.

19. Klein PS and Melton DA: A molecular mechanism for the effect of lithium on development. Proc Natl Acad Sci USA 94: 10330-10334, 1996

20. Verma UN, Surabhi RM, Schmaltieg A, Becerra C and Gaynor RB: Small interfering RNAs directed against B-catenin inhibits the in vitro and in vivo growth of colon cancer cells. Clin Cancer Res 9: 1291-1300, 2003.

21. Roh H, Green DW, Boswell CB, Pippin JA and Drebin JA: Suppression of B-catenin inhibits the neoplastic growth of APCmutant colon cancer cells. Cancer Res 61: 6563-6568, 2001.

22. Utsunomiya T, Doki Y, Takemoto H, Shiozaki H, Yano M, Sekimoto M, Tamura S, Yasuda T, Fujiwara Y and Monden M: Correlation of $B$-catenin and cyclin D1 expression in colon cancers. Oncology 61: 226-233, 2001.

23. Amson RB, Nemani M, Roperch JP, Israeli D, Bougueleret L, LeGall I, Medhioub M, Linares-Cruz G, Lethrosne F, Pasturaud P, Piouffre L, Prieur S, Susini L, Alvaro V, Millasseau P, Guidicelli C, Bui H, Massart C, Cazes L, Bruzzoni-Giovanelli H, Dufour F, Owadi H, Hennion C, Charpak G, Telerman A, et al: Isolation of 10 differentially expressed cDNAs in p53-induced apoptosis: activation of the vertebrate homologue of the Drosophila seven in absentia gene. Proc Natl Acad Sci USA 93: 3953-3957, 1996.

24. Cho M, Gwak J, Park S, Won J, Kim DE, Yea SS, Cha IJ, Kim TK, Shin JG and Oh S: Diclofenac attenuates Wnt/ßcatenin signaling in colon cancer cells by activation of NF-кB. FEBS Lett 579: 4213-4218, 2005.

25. Ghosh S, May MJ and Kopp EB: NF-кB and Rel proteins: evolutionarily conserved mediators of immune responses. Annu Rev Immunol 16: 225-260, 1998. 
26. Gilmore TD, Koedood M, Piffat KA and White DW: Rel/NF-кB/ IкB proteins and cancer. Oncogene 13: 1367-1378, 1996.

27. Bours V, Bentires-Alj M, Hellin AC, Viatour P, Robe P, Delhalle S, Benoit V and Merville MP: Nuclear factor- $\kappa \mathrm{B}$, cancer, and apoptosis. Biochem Pharmacol 60: 1085-1089, 2000.

28. Karim R, Tse G, Putti T, Scolyer R and Lee S: The significance of the Wnt pathway in the pathology of human cancers. Pathology 36: 120-128, 2004.

29. Baeuerle PA and Baltimore D: IкB: a specific inhibitor of the NF-кB transcription factor. Science 242: 540-546. 1998.
30. Yaron A, Hatzubai A, Davis M, Lavon I, Amit S, Manning AM, Andersen JS, Mann M, Mercurio F and Ben-Neriah Y: Identification of the receptor component of the IкB $\alpha$-ubiquitin ligase. Nature 396: 590-594, 1998.

31. Sadot E, Conacci-Sorrell M, Zhurinsky J, Shnizer D, Lando Z, Zharhary D, Kam Z, Ben-Ze'ev A and Geiger B: Regulation of S33/S37 phosphorylated B-catenin in normal and transformed cells. J Cell Sci 115: 2771-2780, 2000

32. Deng J, Miller SA, Wang HY, Xia W, Wen Y, Zhou BP, Li Y, Lin SY and Hung MC: B-catenin interacts with and inhibits $\mathrm{NF}-\mathrm{\kappa B}$ in human colon and breast cancer. Cancer Cell 2: 323-334, 2002. 